\title{
Regulatory Role of miRNA-375 in Expression of BMP15/GDF9 Receptors and its Effect on Proliferation and Apoptosis of Bovine Cumulus Cells
}

\author{
Hongyan Chen ${ }^{\mathrm{a}}$ Chang Liu ${ }^{\mathrm{a}}$ Hao Jiang ${ }^{\mathrm{a}}$ Yan Gao ${ }^{\mathrm{a}}$ Mingqiang Xua Jiawei Wang ${ }^{\mathrm{a}}$ \\ Siyuan Liua Yao Fu ${ }^{a}$ Xulei Sun ${ }^{a}$ Jiajun Xu Lisheng Dai $^{\mathrm{a}} \quad$ Jiabao Zhanga \\ aLaboratory Animal Center, College of Animal Sciences, Jilin University, Changchun, China
}

Key Words

miRNA-375 • BMP15/GDF9 • Cumulus cells • Proliferation • Apoptosis

\begin{abstract}
Background: Bone morphogenetic protein 15 (BMP15) and growth differentiation factor 9 (GDF9) are members of the transforming growth factor beta (TGF- $\beta$ ) superfamily. Through autocrine and paracrine mechanisms, these two factors can regulate cell differentiation, proliferation, and other functions in the ovary locally. Furthermore, GDF9 and BMP15 play vital roles in follicular growth, atresia, ovulation, fertilization, reproduction, and maintenance. Numerous studies have demonstrated a synergy between BMP15 and GDF9. Studies in humans and mice have indicated that the synergy between BMP15 and GDF9 is primarily mediated by the bone morphogenetic protein type II receptor (BMPR2). The BMP15/GDF9 heterodimer needs to bind to the BMPR2-ALK4/5/7-ALK6 receptor complex to activate the SMAD2/3 signaling pathway. However, it is not clear which genes mediate and regulate the effects of the BMP15/GDF9 proteins on bovine cumulus cells (CCs). Methods: Our earlier study showed that BMPR2 is a gene that is directly targeted and regulated by miR-375. Therefore, we designed and synthesized an miR-375 mimics/inhibitor and regulated BMPR2 expression in bovine CCs by the overexpression or inhibition of miR-375. After the overexpression or inhibition of miR375 , the apoptosis rate of bovine CCs was measured by flow cytometry; changes in critical gene expression were measured by RT-qPCR and western blot assays; and the proliferation of bovine CCs was measured by CCK-8 assay. Results: In bovine CCs, the overexpression of miR375 resulted in decreased BMPR2 and ALK7 expression, whereas the inhibition of miR-375 caused increased BMPR2 and ALK7 expression. The overexpression of miR-375 attenuated the proliferation ability and significantly increased the apoptosis rate of bovine CCs, whereas the inhibition of miR-375 did not significantly change the proliferation ability or apoptosis rate. Conclusions: $B M P R 2$, a target of miR-375, is regulated by this molecule, thereby affecting expression of BMP15/GDF9 receptors, and the proliferation and apoptosis of bovine CCs.
\end{abstract}

H. Chen and C. Liu contributed equally to this article. 


\section{Introduction}

Ovarian follicles are the basic units of development in the mammalian ovary. Mammalian ovarian follicles consist of germ cells, or oocytes, wrapped in several layers of somatic cells. As follicles develop, cavities appear within the follicle, and the layers of somatic cells divide into two different subtypes. Granulosa cells distributed in the mural layers of follicles are called mural granulosa cells (Mural granulosa , MGC), and granulosa cells surrounding the oocytes are called cumulus cells (Cumulus, CC). MGCs and CCs have different functions [1]. MGCs exhibit higher steroid synthesis activity than CCs and facilitate the synthesis of relevant steroids by expressing higher mRNA levels of steroid synthase [2, 3]. CCs produce hyaluronidase and undergo expansion in response to follicle-stimulating hormone. During follicle development, CCs pass through the zona pellucida utilizing highly specific cytoplasmic projections which approach the oocyte membranes, forming gap junctions to deliver nutrients to the oocytes. Subsequently, the oocytes secrete specific growth factors and promote CC proliferation and expansion $[4,5]$. The crosstalk established between CCs and oocytes directly affects follicle development and oocyte maturation [6-8].

Extensive studies have shown that complex signaling transduction occurs between CCs and oocytes and that the regulation of follicle and oocyte development occurs at the molecular level. Bone morphogenetic protein 15 (BMP15, also called GDF9B) and growth differentiation factor 9 (GDF-9) are two growth factors secreted by oocytes. GDF9 and BMP15 bind to their corresponding receptors in CCs, leading to a cascade of reactions of downstream genes. These reactions affect CC proliferation and apoptosis and thereby regulate follicle development and oocyte maturation [9]. GDF9 and BMP15 have a high degree of amino acid homology and similar protein structure. Both factors are closely associated by expression pattern and function in the ovary. Increasing evidence has shown a synergistic relationship between GDF9 and BMP15 [10-18]. However, the mechanisms of self-regulation by CCs of the expression of BMP15 and GDF9 receptors and the mechanism by which BMP15 and GDF9 affect CC proliferation and apoptosis remain critical issues that have yet to be determined.

A study on BMP15 and GDF9 signaling has shown that after binding to bone morphogenetic protein type I (Bone morphogenetic protein receptor type-1B, BMPR1B,

also called ALK6) and type II receptors (Bone morphogenetic protein receptor type II , BMPR2) in CCs, BMP15 can activate the SMAD1/5/8 signaling pathway, stimulate a series of downstream cascade reactions, mediate transcription and translation processes, and induce cell proliferation $[19,20]$. As the same as BMP15, the GDF 5/6/7 of TGF- $\beta$ family member can also play a biological role through smad 1/5/8 albumen, like the different function of GDF-5 in the structural and functional maintenance of intervertebral disk, GDF6 in the promotion of cartilage expression and GDF-7 in mammary cancer [21-23].GDF9 can activate the SMAD2/3 signaling pathway by binding to the ALK5 type I receptor and BMPR2 in CCs [24-27]. The synergy between BMP15 and GDF9 is mediated by BMPR2 [11]. The BMP15/GDF9 heterodimer needs to bind to a receptor complex, namely the BMPR2ALK4/5/7-ALK6 complex, to activate SMAD2/3 signaling [13, 14, 18, 28]. While the synergy interaction of BMP15/GDF9 or GDF9 alone is known to activate SMAD2/3 signaling, the mechanism and the involved genes by which BMP15/GDF9 produces an effect in bovine CCs remains unknown. Furthermore, our previous studies found that BMPR2 is a direct target of miR-375 in bovine cumulus cells [29]. While the individual or synergistic effect of BMP15/ GDF9 requires binding to BMPR2, the mechanism by which miR-375 regulate BMPR2 expression and thereby balance the effect of BMP15/GDF9 has yet to be determined.

\section{Materials and Methods}

Cumulus cell separation and culture

Healthy bovine ovaries with normal morphology and no corpus luteum were collected from a slaughterhouse. The ovaries were placed into normal saline at $25^{\circ} \mathrm{C}$ and delivered to the laboratory 
within 2 hours of collection. Follicular fluid was extracted from 3-8-mm diameter ovarian follicles and transferred into HEPES (Amresco) buffer. Cumulus-oocyte complexes (COCs) with more than five tightly wrapped layers of CCs and with uniformly distributed oocyte cytoplasm were selected under a dissecting microscope. CCs and oocytes were completely separated after digestion with $0.1 \%$ hyaluronidase(Sigma), and denuded oocytes were collected. The CCs were centrifuged and washed with phosphate-buffered saline (PBS) and subsequently collected and counted. The cells were cultured using DMEM/F12 medium (containing $10 \%$ fetal bovine serum and double antibiotics) and placed in a $5 \% \mathrm{CO}_{2}$ incubator at $38.5^{\circ} \mathrm{C}$. DMEM/F12 medium(Gibico); trypsin(Gibico); fetal bovine serum(BI); penicillin-streptomycin solution (double antibiotics) (Hyclone).

Transfection of bovine cumulus cells

miRNA-375 mimics/inhibitor and BMPR2 siRNA were designed and synthesized by Shanghai GenePharma Co., Ltd., China. The sequences are listed in Table 1.

The CCs were seeded at $1.0 \times 10^{5}$ cells/well into a 12 -well plate. When the cultures reached $60 \%$ confluence, the spent medium was exchanged with fresh DMEM/F12 complete medium, and the cells were transfected. The transfection procedure was as follows: based on proportions of $2 \mu \mathrm{l}$ of Lipofectamine ${ }^{\mathrm{TM}}$ 2000 (Invitrogen)and 40 pmol of siRNA (Gene Pharma, China) per well in a 12-well plate, each well was first provided with $100 \mu \mathrm{l}$ of serum-free, antibiotic-free DMEM medium and incubated at room temperature for 5 min. Then, Lipofectamine ${ }^{\mathrm{TM}} 2000$ and siRNA were added, and the cells were incubated at room temperature for $20 \mathrm{~min}$. Finally, $200 \mu \mathrm{l}$ of siRNA-Lipofectamine ${ }^{\mathrm{TM}} 2000$ mixture was added to each well, and the cells were incubated at $37^{\circ} \mathrm{C}$ for $48 \mathrm{~h}$.

Table 1. Sequences of miRNA-375 mimics/NC, miRNA-375inhibitor/iNC, BMPR2 siRNA/NC

\begin{tabular}{|c|c|}
\hline Name & Sequence $\left(5^{\prime}-3^{\prime}\right)$ \\
\hline $\begin{array}{l}\text { has-miR-375 mimics } \\
\text { has-miR-375 mimics NC } \\
\text { has-miR-375 inhibitor } \\
\text { has-miR-375 inhibitor NC } \\
\text { BMPR2-bos-1703 } \\
\text { BMPR2-bos-NC }\end{array}$ & $\begin{array}{l}\text { sense: UUUGUUCGUUCGGCUCGCGUGA } \\
\text { antisense: ACGCGAGCCGAACGAACAAAUU } \\
\text { sense: UUCUCCGAACGUGUCACGUTT } \\
\text { antisense: ACGUGACACGUUCGGAGAATT } \\
\text { sense: UCACGCGAGCCGAACGAACAAA } \\
\text { sense: CAGUACUUUUGUGUAGUACAA } \\
\text { sense: GCUUGUGAUGGAGUAUUAUTT } \\
\text { antisense: AUAAUACUCCAUCACAAGCTT } \\
\text { sense: UUCUCCGAACGUGUCACGUTT } \\
\text { antisense: ACGUGACACGUUCGGAGAATT }\end{array}$ \\
\hline
\end{tabular}

Table 2. Primers used for RT-qPCR analysis

\begin{tabular}{ll}
\hline Primer name & Primer sequence \\
\hline miR-375-RT & GTCGTATCCAGTGCAGGGTCGAGGTATTCGCACTGGATACGACTCACGC \\
miR-375-F & GAGCATTTTGTTCGTTCGGC \\
mRR-375-R & AGTGCAGGGTCCGAGG \\
U6-RT & CGCTTCACGAATTTGCGTGTC \\
U6-F & TCGCTTCGGCAGCACATATAC \\
U6-R & GCGTGTCATCCTTGCGCAG \\
ALK4-F & GGCTCCCTGTTGACTATCT \\
ALK4-R & AGTTCCCACCCTCTGGTT \\
ALK5-F & CATATTGCTGCAACCAGG \\
ALK5-R & AAAGGGCGATCTAACGAG \\
ALK6-F & AAACGGTCCCTCTATGA \\
ALK6-R & GAGTGTTGGGTGGTATGT \\
ALK7-F & GGAGGAGGCTGAGGAAGT \\
ALK7-R & CACAGTAGTTGGCGTGGTAG \\
BMPR2-F & GCATTGGCATCAGTCT \\
BMPR2-R & CCTTGTTTGGGTCTC \\
BCl-2-F & AGAGCGTCAACCGGGAGAT \\
BCl-2-R & GACAGCCAGGAGAAATCAAACA \\
Bax-F & ATCGGAGATGAATTGGACAG \\
Bax-R & CCTTGAGCACCAGTTGC \\
GAPDH-F & AAGTTCAACGGCACAGTCA \\
GAPDH-R & GTCATAAGTCCCTCCACGAT \\
\hline
\end{tabular}




\section{Cellular Physiology Cell Physiol Biochem 2017;41:439-450 \begin{tabular}{l|l|l} 
and Biochemistry Published onIIne: January 27, 2017 & $\begin{array}{l}\text { C) } 2017 \text { The Author(s). Published by S. Karger AG, Basel } \\
\text { www.karger.com/cpb }\end{array}$ \\
\hline
\end{tabular} \\ Chen et al.: miR-375 Roles in the Bovine Cumulus Cells}

RNA extraction and quantitative real-time reverse transcription polymerase chain reaction (RT-qPCR)

Total RNA was extracted from the cells using Tripure Isolation Reagent(Roche). The quality of total RNA extracted and the RNA concentration were determined using a NanoDrop 2000(Thermo). cDNA was synthesized by reverse transcription using a fast reverse transcription kit (TIANGEN, China). The expression levels of miR-375 and other genes in cells were assayed by RT-qPCR using a SYBR Green method, with cDNA as a template and U6 and GAPDH as internal controls. The amplification was conducted using an Eppendorf quantitative real-time PCR machine(Germany). A $20 \mu \mathrm{l}$ RT-qPCR reaction contained $20 \mu \mathrm{l}$ of SuperReal PreMix Plus(TIANGEN, China), $8 \mu \mathrm{l}$ of deionized water, $1 \mu \mathrm{l}$ of cDNA, and $0.5 \mu$ l each of upstream and downstream primers $(10 \mathrm{mM})$. Primers were designed using Prime 5.0 and synthesized by Bio-Serve, Co., Ltd., China. The primer sequences are shown in Tables 2 .

The qPCR program comprised denaturation at $95^{\circ} \mathrm{C}$ for 120 seconds and 40 cycles of PCR (denaturation at $95^{\circ} \mathrm{C}$ for $15 \mathrm{sec}$, annealing at $55-60^{\circ} \mathrm{C}$ for $15 \mathrm{sec}$, and extension at $72^{\circ} \mathrm{C}$ for $30 \mathrm{sec}$ ). The melting cycle comprised $95^{\circ} \mathrm{C}$ for $15 \mathrm{sec}, 60^{\circ} \mathrm{C}$ for $15 \mathrm{sec}$, and $95^{\circ} \mathrm{C}$ for $15 \mathrm{sec}$. The specificity of the RT-PCR products was verified by melting curve analysis. Each cDNA sample had three triplicates, and the results were calculated and analyzed using the mean threshold cycle $\left(\mathrm{C}_{\mathrm{t}}\right)$ for each sample. Relative expression levels were calculated using the $2^{-\Delta \Delta C T}$ method.

\section{Western blot analysis}

After the medium was discarded, the cells were washed with PBS, digested with $0.25 \%$ trypsin (Gibico) for $5 \mathrm{~min}$, and harvested into centrifuge tubes. Total protein was extracted from bovine CCs with lysis buffer(20mM Tris(pH7.5), $150 \mathrm{mM} \mathrm{NaCl}, 1 \%$ Triton X-100, sodium pyrophosphate, $\beta$-glycerophosphate, EDTA, $\mathrm{Na}_{3} \mathrm{VO}_{4^{\prime}}$ leupeptin) (Beyotime, China) containing $10 \mathrm{mmol} / \mathrm{L}$ phenylmethylsulfonyl fluoride (PMSF; Beyotime, China), and the protein concentration was measured by Bradford method. Next, $50 \mu \mathrm{g}$ of protein sample was mixed with $2 \times$ loading buffer (TIANGEN, China), denatured at $95^{\circ} \mathrm{C}$ for $5 \mathrm{~min}$, separated by sodium dodecyl sulfate polyacrylamide gel electrophoresis (SDS/PAGE) on a $12 \%$ gel and transferred to a PDVF membrane $(0.22 \mathrm{mM}$, Millipore, Bedford, MA, USA). The membrane was blocked for $2 \mathrm{~h}$ and then incubated with primary antibodies that were diluted with blocking buffer (ALK4 goat polyclonal IgG, 1:1000 ; ALK5 rabbit polyclonal IgG,1:1000; ALK6 rabbit polyclonal IgG,1:2000; ALK7 rabbit polyclonal IgG,1:2000; BMPR2 goat polyclonal IgG;Bcl-2 rabbit polyclonal IgG,1:1000; Bax rabbit polyclonal IgG,1:1000;GAPDH rabbit polyclonal IgG,1:1000 dilution) (all the catalog numbers of antibodies: sc-xxxx/abxxxx) overnight at $4^{\circ} \mathrm{C}$ on a shaker. The membrane was washed with Tris-buffered saline containing $1 \%$ Tween-20(Sigma) three times, and then incubated with the corresponding secondary antibodies (rabbit anti-goat IgG-HRP or goat anti-rabbit IgG-HRP; $1: 10000$ dilution) at room temperature (RT) for $1 \mathrm{~h}$. All antibodies were purchased from Santa Cruz Biotechnology, Inc. (Santa Cruz, CA, USA) and Abcam(UK).ALK4 (Santa Cruz,sc-31297), ALK5 (Santa Cruz,sc-398), ALK6 (abcam,ab155058), ALK7 (abcam,ab71539), BMPR2 (Santa Cruz,sc-5682), Bcl-2 (Santa Cruz,sc-492), BAX (Santa Cruz,sc-493),GAPDH(Santa Cruz,sc-25778).After the membrane was washed three times with Tris-buffered saline containing $1 \%$ Tween-20, the target protein bands were imaged and analyzed using the Tanon-5200 automated chemiluminescence analyzer (Tanon Science and Technology Co., Ltd., Shanghai, China).

\section{CCK-8 analysis of bovine CC proliferation}

(1) Cells were seeded at $1.0 \times 10^{4}$ cells/well in a 96-well plate. Each well had $100 \mu$ l of culture medium, and three wells were assigned to each group. Wells on the plate margins were filled with sterile PBS, and control wells were supplied with medium only.

(2) When the cultures reached $60 \%$ confluence, the wells were exchanged for fresh complete DMEM/ F12 medium. Subsequently, transfection was started. The plate was pre-incubated in an incubator $\left(37^{\circ} \mathrm{C}, 5 \%\right.$ $\mathrm{CO}_{2}$ ) for $0,1,2,3,4$, and 5 days.

(3) CCK-8 solution $(10 \mu \mathrm{l})$ was added to each well.

(4) The plate was incubated for $2.5 \mathrm{~h}$.

(5) The optical density in each well was measured at $450 \mathrm{~nm}$ using a plate reader calibrated to a blank well. For each group, the mean value of the three wells was obtained to determine a proliferation curve. Cell Counting Kit-8(Dojindo) 


\section{Cellular Physiology Cell Physiol Biochem 2017;41:439-450 \\ \begin{tabular}{ll|l} 
and Biochemistry Published onlıne: January 27, 2017 & $\begin{array}{l}\text { (C) } 2017 \text { The Author(s). Published by S. Karger AG, Basel } \\
\text { www.karger.com/cpb }\end{array}$ \\
\hline
\end{tabular} \\ Chen et al.: miR-375 Roles in the Bovine Cumulus Cells}

Flow cytometry analysis of CC apoptosis

The following procedure was conducted based on provided instructions in a FITC Annexin V Apoptosis Detection Kit I (BD, USA).

(1) Cell harvest: At $48 \mathrm{~h}$ of cell transfection, cells and cell debris were harvested by digestion with EDTA-free trypsin.

(2) Cell staining: The cells were washed with PBS and centrifuged two to three times (5 min each) at $4^{\circ} \mathrm{C}, 800 \times \mathrm{g}$. Then, $100 \mu \mathrm{l}$ of PBS was added into each centrifuge tube, followed by additions of $5 \mu \mathrm{l}$ of FITC solution and $5 \mu \mathrm{l}$ of propidium iodide $(20 \mu \mathrm{g} / \mathrm{ml})$. The cells were incubated at room temperature in the dark for $15 \mathrm{~min}$.

(3) Cell assay: The samples were assayed within $2 \mathrm{~h}$ using a flow cytometer (BD, USA). Apoptotic and dead cells were distinguished by staining with propidium iodide and FITC.

\section{Statistical analysis}

All experiments were repeated three times. Experimental data were analyzed using the analysis of variance (ANOVA) module of the SPSS16.0 statistical software. The data are expressed as means \pm standard deviations $(\bar{x} \pm \mathrm{s}) .{ }^{*} \mathrm{P}<0.05$ represented a significant difference; and ${ }^{* *} \mathrm{P}<0.01$ represented a highly significant difference.

\section{Results}

The effects of miRNA-375 mimics/inhibitor transfection

According to the qPCR results, miR-375 expression was significantly higher in the miR375 mimics group than in the miR-375 mimics negative control $(\mathrm{NC})$ group $(\mathrm{P}<0.01)$ (Fig. 1A) . miR-375 expression was significantly lower in the miR-375 inhibitor group than in the miR-375 inhibitor negative control (iNC) group ( $<0.01$ ) (Fig. 1B). These results showed that by transfection, the designed miR-375 mimics/inhibitor achieved the desired promotion and inhibition in bovine CCs and thus could be used for the following experiments.

The mRNA expression levels of ALK4/ALK5/ALK6/ALK7/BMPR2/Bcl-2/Bax after the overexpression/inhibition of the miRNA-375 and transfection of BMPR2 SiRNA

The qPCR results showed that ALK4, ALK5, and ALK6 mRNA expression levels were not significantly different in the miR-375 mimics/miR-375 inhibitor groups compared with the NC/iNC groups (P > 0.05) (Figs. 2A and 2B). ALK7, BMPR2, and Bcl-2 mRNA expression levels were significantly lower in the miR-375 mimics group than in the NC group $(\mathrm{P}<0.05)$ (Fig. 2A). Bax mRNA expression levels were significantly higher in the miR-375 mimics group than in the NC group ( $\mathrm{P}<0.05$ ) (Fig. 2A). ALK7, BMPR2 mRNA expression levels were
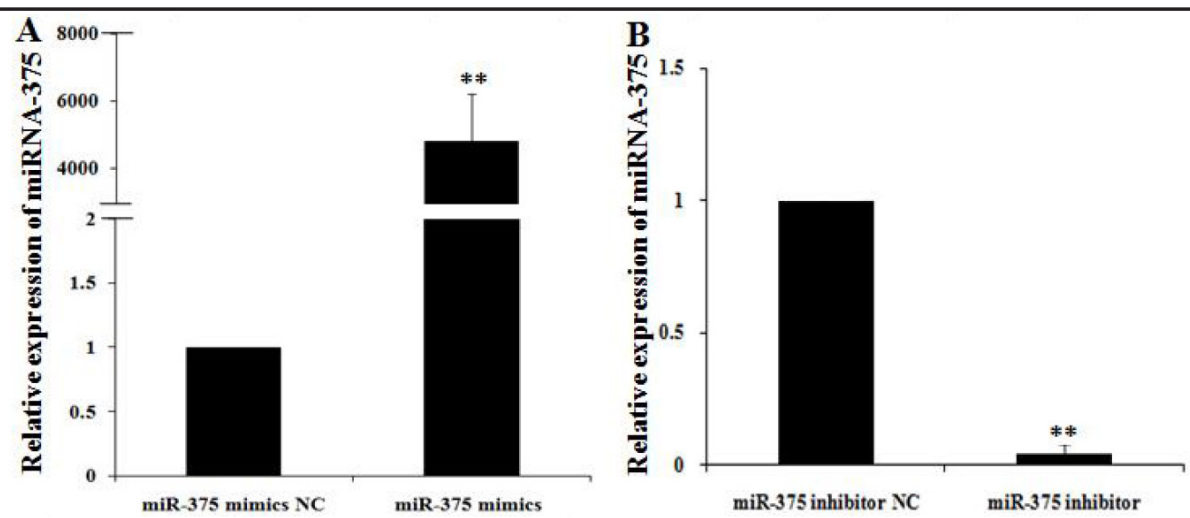

Fig. 1. The relative expression of miR-375 in cumulus cells with miR-375 mimics/inhibitor transferction. A. miR-375 was up-regulated in cumulus cells with miR-375 mimics transferction ( $<<0.01)$. B. miR-375 was down-regulated in cumulus cells with miR-375 inhibitor transferction $(\mathrm{p}<0.01)$. 


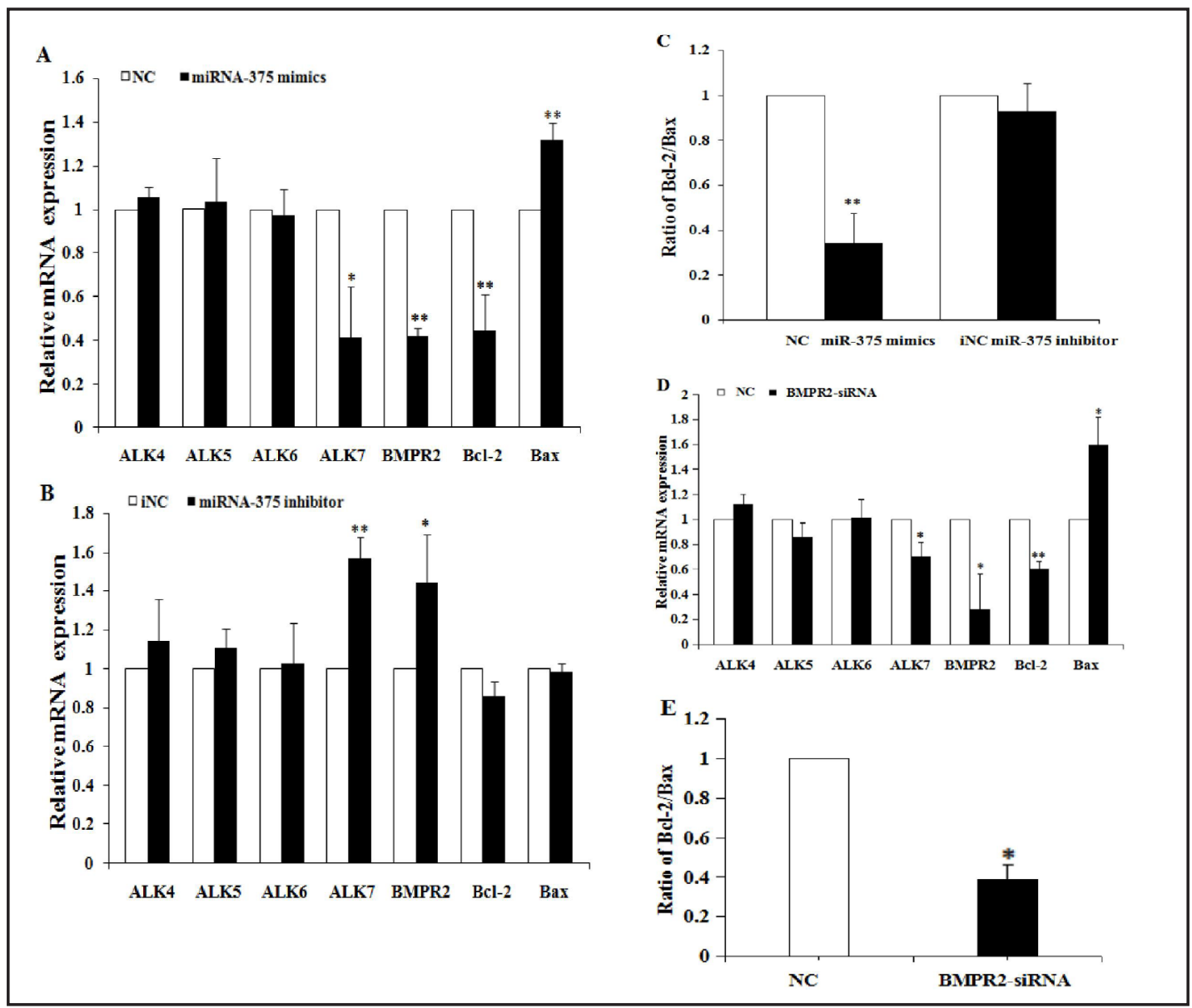

Fig. 2. Different gene expression in cumulus cells with miR-375 mimics/inhibitor transferction. A.ALK4/ ALK5/ALK6 were no significant change( $>00.05), A L K 7 / B M P R 2 / B c l-2$ were down-regulated(p<0.05) and Bax was up-regulated in cumulus cells with miR-375 mimics transfection $(\mathrm{p}<0.01)$; B.ALK4/ALK5/ALK/ Bcl-2/Bax were no significant change( $p>0.05)$ and ALK7/BMPR2 were down-regulated in cumulus cells with miR-375 inhibitor transfection $(\mathrm{p}<0.05)$; C. The ratio of Bcl-2 to Bax was down- regulated in cumulus cells with miR-375 mimics transfection $(\mathrm{p}<0.01)$ and the ratio of Bcl-2 to Bax was no significant change in cumulus cells with miR-375 inhibitor transfection ( $p>0.05$ ); D.ALK4/ALK5/ALK6 were no significant change( $p>0.05)$,ALK7/BMPR2/Bcl-2 were down-regulated $(\mathrm{p}<0.05)$ and Bax was up-regulated in cumulus cells with BMPR2-siRNA transfection $(\mathrm{p}<0.05)$; E.The ratio of Bcl-2 to Bax was down- regulated in cumulus cells with BMPR2-siRNA transfection $(\mathrm{p}<0.05)$.

significantly higher in the miR-375 inhibitor group than in the iNC group $(\mathrm{P}<0.05)$ (Fig. 2B). Bcl-2 and Bax mRNA expression levels did not differ significantly in the miR-375 inhibitor group compared with the iNC group (P > 0.05) (Fig. 2B).In the miR-375 mimics group, there was a significantly lower the ratio of Bcl-2 to Bax compared with that in the NC group $(\mathrm{P}<$ $0.01)$, whereas in the miR-375 inhibitor group, no significant difference was found when compared with the iNC group (P > 0.05) (Fig. 2C).

To further clarify the effects of miR-375 on expression of ALK7, Bcl-2, and Bax, Knockdown of BMPR2 were performed in bovine CCs. The results were consistent with the miR-375 mimics group (Figs. 2D). Meanwhile, the suppression of BMPR2 significantly reduced the ratio of Bcl-2 to Bax (Figs. 2E).These results indicated that the change of ALK7, Bcl-2, and Bax were caused by BMPR2, but not miR-375. 


\section{Cellular Physiology Cell Physiol Biochem 2017;41:439-450

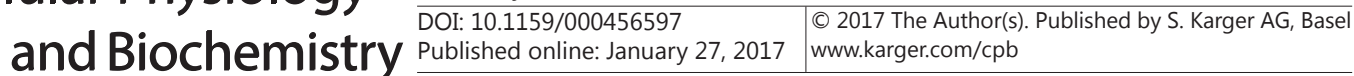 \\ Chen et al.: miR-375 Roles in the Bovine Cumulus Cells}

Fig. 3. Western blot analyses of ALK4/ALK5/ ALK6/ALK7/BMPR2/Bcl-2 and Bax proteins in cumulus cells. Optical density of the bands was determined by Image J software and normalized using internal reference gene (GAPDH).1. miR-375 mimics negative control (NC) group; 2. miR-375 mimics group; 3. miR-375 inhibitor negative control (iNC) group; and 4. miR-375 inhibitor group. A-G show ALK4/ALK5/ALK6/ALK7/BMPR2/ Bcl-2 and Bax protein expression levels, respectively, in cells after overexpression or inhibition of miR-375; H. Relative ALK4/ALK5/ ALK6/ALK7/BMPR2/Bcl-2 and Bax protein expression levels in the miR-375 mimics/NC groups; I. Relative ALK4/ALK5/ALK6/ALK7/ BMPR2/Bcl-2 and Bax protein expression levels in the miR-375 inhibitor/iNC groups; G. The ratio of Bcl-2 to Bax was down- regulated in cumulus cells with miR-375 mimics transfection $(p<0.01)$ and the ratio of Bcl-2 to Bax was no significant change in cumulus cells with miR-375 inhibitor transfection ( $p>0.05$ ).

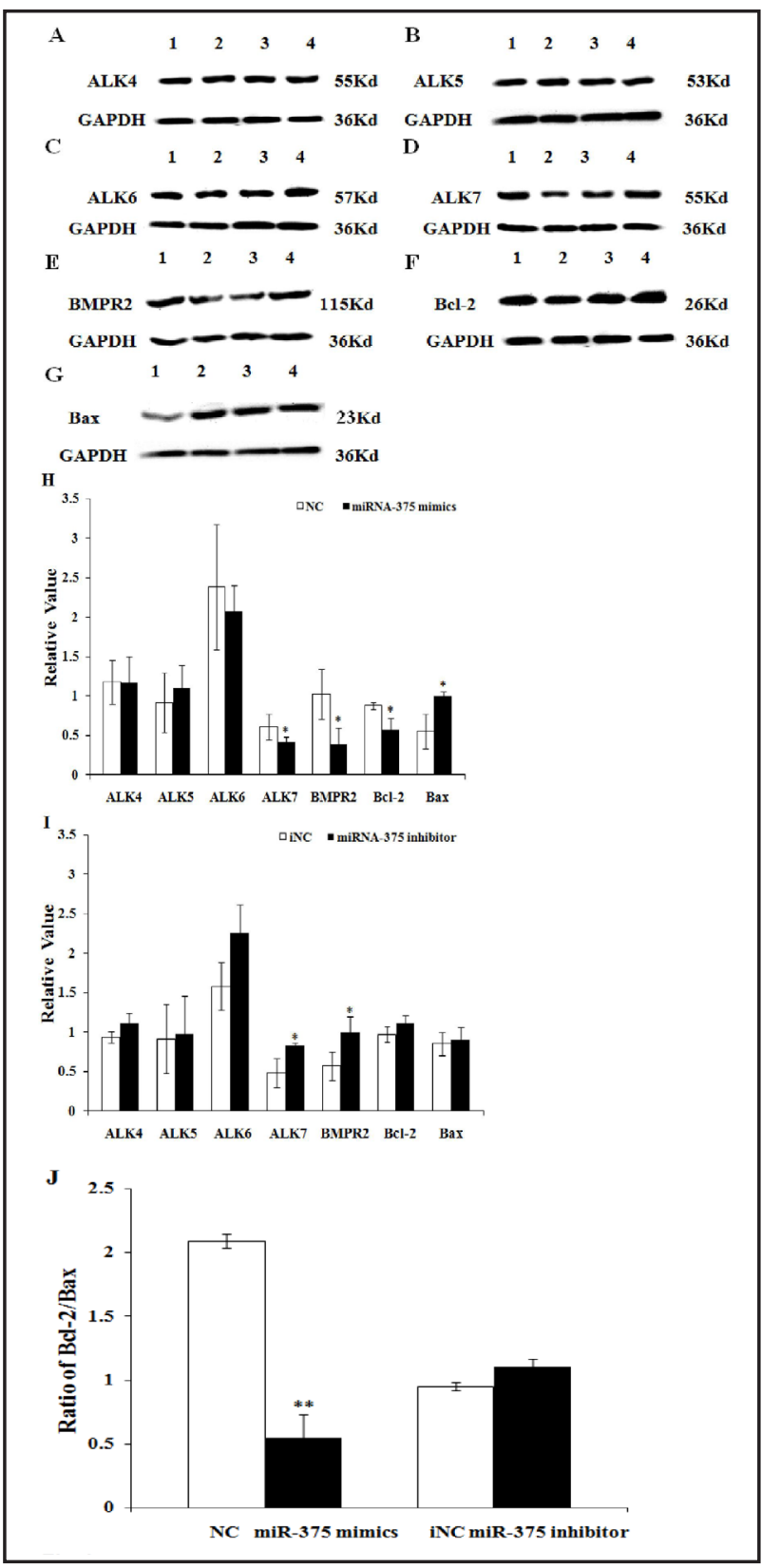

The expression levels of ALK4/ALK5/ALK6/ALK7/BMPR2/Bcl-2 and Bax proteins after the overexpression/inhibition of the miRNA-375

The results showed that after transfection with the miR-375 mimics, ALK7, BMPR2, and Bcl-2 protein expression levels were downregulated ( $\mathrm{P}<0.05$ ) (Figs. 3D,3E and 3F); ALK4, ALK5, ALK6 protein expression levels were not significantly different (Figs. 3A,3B and 3C); Bax protein expression levels increased $(\mathrm{P}<0.05)$ (Fig. $3 \mathrm{G}$ ); and the ratio of Bcl-2 to Bax highly significantly decreased $(\mathrm{P}<0.01$ ) (Fig. 3J) when compared with the NC group. After transfection with the miR-375 inhibitor, ALK7 and BMPR2 protein expression levels were upregulated $(\mathrm{P}<0.05)$ (Figs. 3D,3E); ALK4, ALK5, ALK6, Bcl-2, and Bax protein expression levels were not significantly different(Figs. 3A,3B,3C,3F and $3 \mathrm{G}$ ); and the ratio of Bcl-2 to Bax did not significantly change when compared with the iNC group(Fig. 3J). Western blot results also indicated that the expression level of miR-375 directly affected the changes in ALK7 and BMPR2 expression. Furthermore, the overexpression of miR-375 significantly reduced the ratio of $\mathrm{Bcl}-2$ to Bax . 
Fig. 4. Cell viability analyses of the growth curve in cumulus cells by CCK-8 method. A. miR-375 mimics inhibition of cell growth could be observed after $72 \mathrm{~h}$ when the cells were transfected $(\mathrm{p}<0.05)$; B. miR375 inhibitor was no significant effect on the cells after transfection ( $p>0.05)$.

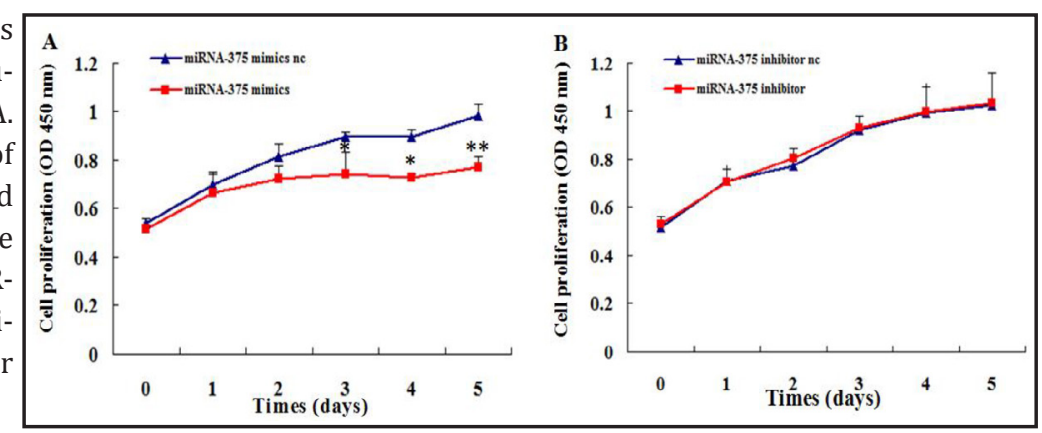

Fig. 5. Flow cytometry was used to observe the apoptosis of cumulus cells by staining with annexinVFLUOS/PI. A. miR-375 mimics NC group; B miR-375 mimics; C. miR375 inhibitor NC; D. miR-375 inhibitor; E. The apoptosis rates of cumulus cells after transfection with miR-375 mimics NC, miR-375 mimics, miR-375 inhibitor NC and miR-375 inhibitor. The apoptosis rates show that miR-375 mimics induces apoptosis of cumulus cells in vitro $(\mathrm{p}<0.01)$.
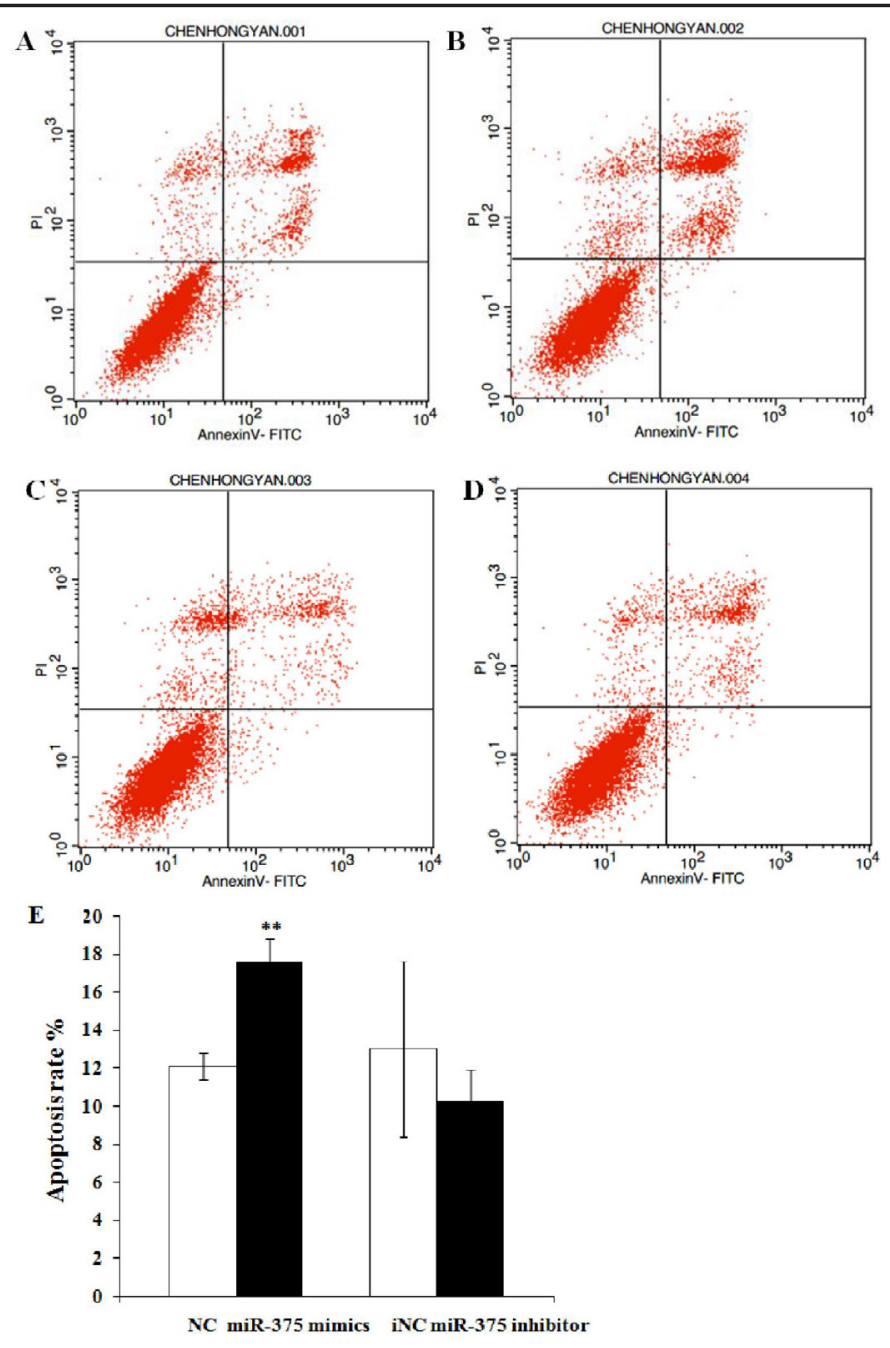

Effect of miRNA-375 mimics/inhibitor on the proliferation of cumulus cells

CCK-8 assay was conducted to measure the in vitro proliferation ability of bovine CCs after transfection with miR-375 mimics or miR-375 inhibitor and to determine the cell growth curve. As shown in Fig. 4A, cell proliferation ability gradually weakened 0-72 h after transfection. At $72 \mathrm{~h}$, the cell proliferation ability was significantly diminished in the miR-375 mimics group compared with the NC group $(\mathrm{P}<0.05)$. As shown in Fig. 4B, the cell proliferation ability was not significantly different in the miR-375 inhibitor group when compared with the iNC group ( $\mathrm{P}>0.05)$. These results suggested that the promotion of miR-375 expression inhibited the in vitro proliferation ability of bovine CCs, whereas the 
inhibition of miRNA-375 expression had no significant effect on the in vitro proliferation ability of bovine CCs.

Effect of miRNA-375 mimics/inhibitor on the apoptosis of cumulus cells

Flow cytometry was used to assay apoptosis in the miR-375 mimics/NC and miR-375 inhibitor/iNC groups of the bovine CCs. The results showed that the apoptosis rate of bovine CCs significantly increased in the miR-375 mimics group compared with the miR-375 mimics NC group ( $\mathrm{P}<0.01)$ (Figs. 5A, 5B and 5E). No significant difference was observed in the apoptosis rate of bovine CCs in the miR-375 inhibitor group compared with the iNC group ( $P>0.05$ ) (Figs. 5C, 5D and 5E). These results suggested that the promotion of miR-375 expression facilitated the in vitro apoptosis of bovine CCs, whereas the inhibition of miR-375 expression had no significant effect.

\section{Discussion}

Both BMP15 and GDF9 are members of the TGF- $\beta$ superfamily. Oocyte-derived GDF9 and BMP15 have recently been found to be important regulators of follicular growth and ovarian function. Through autocrine and paracrine mechanisms, GDF9 and BMP15 can regulate cell differentiation, proliferation, and other functions in the ovary locally. These two factors play vital roles in follicular growth and atresia, ovulation, fertilization, reproduction and maintenance. BMP15 can regulate particular regulator secretion and receptor expression (e.g., follistatin, KIT ligand, and follicle stimulating hormone receptor) in the ovary and control the number of dominant follicles before ovulation, which is a determinant for the quantity and quality of ovulation. Moreover, BMP15 can significantly inhibit apoptosis and promote proliferation in CCs. BMP15 also induces particular gene expression in CCs, such as HAS2, PTX3, and PTGS2, and thereby facilitates CC expansion, optimizes the microenvironment of oocytes, and promotes oocyte maturation and ovulation [30-33]. GDF9, which has similar functions as BMP15, can inhibit LH/CG receptor and KIT ligand expression in CCs, induce CC expansion-associated gene expression, and facilitate oocyte maturation and ovulation [34-36]. The addition of GDF9 or BMP15 into mature culture broths of murine and bovine oocytes can significantly improve the quantity and quality of blastocysts and fetal survival rates after embryo transfer [37-39].

Furthermore, as is known, GDF9 and BMP15 alone or in synergistic combination can play a significant role. The GDF9/BMP15 heterodimer is the most biologically active ligand among genes that regulate CC expansion $[14,18]$. Therefore, in light of the presented experimental results, we speculate that in bovine CCs cultured in vitro, the GDF9/BMP15 heterodimer may bind to BMPR2-ALK7-ALK6 to form a receptor complex and induce SMAD2/3 phosphorylation and thereby regulate the expression of CC expansion-associated genes (PTX3/HAS2 /PTGS2). BMPR2 is a target gene of miR-375 [29]. Thus, miR-375 regulates the elevation and reduction of BMPR2 expression and thereby modulates the SMAD2/3 pathway involving the GDF9/BMP15 heterodimer, affecting the proliferation and apoptosis of bovine CCs. BMPR2 and ALK7 are type II and type I receptors, respectively; ALK6 serves as an auxiliary receptor (Fig. 6).

Oocyte-secreted BMP15 and GDF9 can facilitate cell proliferation by promoting the division of granulosa cells and CCs [40]. These two factors can promote Bcl-2 expression and inhibit Bax expression in granulosa cells and CCs. In the current study, when the in vitro cultured CCs overexpressed miR-375, the density of BMPR2 and ALK7 receptors decreased. The effect of BMP15/GDF9 should therefore be reduced in the bovine CCs, resulting in decreased cell proliferation ability and subsequent apoptosis. When miR-375 was inhibited, the levels of BMPR2 and ALK7 receptors increased in the cells. However, the BMP15 and GDF9 levels were possibly limited because the bovine CCs were cultured in vitro. Consequently, cell proliferation and apoptosis did not significantly change compared with the control group. 


\section{Cellular Physiology

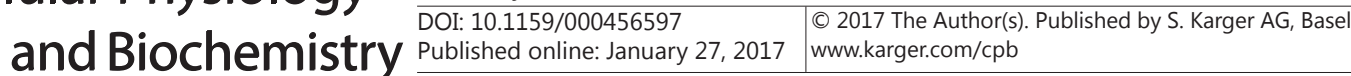 \\ Chen et al.: miR-375 Roles in the Bovine Cumulus Cells}

Fig. 6. The effects of miR-375 on expression of BMP15/GDF9 receptors and its effect on proliferation and apoptosis in bovine cumulus cells.

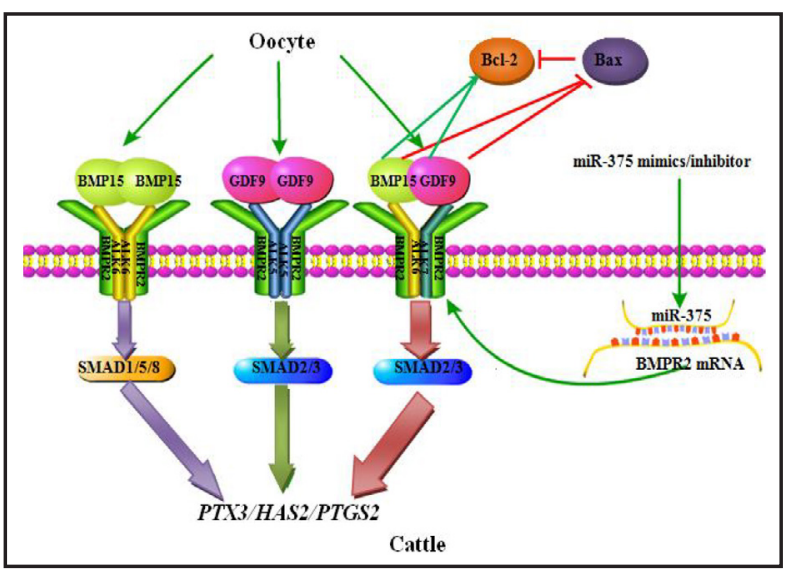

Combined with our conclusion from bovine CCs cultured in vitro, we can also suggest the miR-375 regulation mechanism of BMP15/GDF9-ALK7/ALK6-BMPR2 complex in bovine CCs. The GDF9/BMP15 heterodimer binds to BMPR2-ALK7-ALK6, forming a receptor complex and inducing SMAD2/3 phosphorylation. However, in the body of cattle, upon the overexpression of miR-375, BMPR2/ALK7 receptor levels decrease, and therefore, the signalling level is reduced, leading to diminished proliferation ability and apoptosis in bovine CCs.

Numerous in vitro experiments have shown that the physiological effects of GDF9 and BMP15 are species-dependent. Because the physiological and reproductive forms of different species are variable, their mechanisms of action are also not identical [41-43]. In the present study, we investigated the effects of miRNA-375 mimics/inhibitors on GDF9/ BMP15 receptor expression. Our findings provide an important reference for understanding the molecular regulation mechanism of follicle development and oocyte maturation. In future experiments, we will analyze the effects of miR-375 on critical signaling proteins (e.g., SMAD2/3 and SMAD1/5/8) and CC expansion-associated genes (PTX3, HAS2, and PTGS2) in the presence or absence of BMP15 and/or GDF9. These results will provide a theoretical basis for revealing the mechanism of follicle and oocyte development and offer theoretical support for improving the in vitro maturation system of oocytes.

\section{Acknowledgments}

Reserch was supported by the National Natural Science Foundation of China (3157130295), the earmarked fund for Modern Agro-industry Technology Research System(CARS-38).

\section{Disclosure Statement}

The authors have no conflict of interest.

\section{References}

$\checkmark 1$ Eppig JJ, Chesnel F, Hirao Y, O'Brien MJ, Pendola FL, Watanabe S, Wigglesworth K: Oocyte control of granulosa cell development: how and why. Hum Reprod 1997;12:127-132.

-2 Whitelaw PF, Smyth CD, Howles CM, Hillier SG: Cell-specific expression of aromatase and LH receptor mRNAs in rat ovary. J Mol Endocrinol 1992;9:309-312.

-3 Zlotkin T, Farkash Y, Orly J: Cell-specific expression of immunoreactive cholesterol side-chain cleavage cytochrome P-450 during follicular development in the rat ovary. Endocrinology 1986;119: 2809-2820. 


\section{Cellular Physiology Cell Physiol Biochem 2017;41:439-450

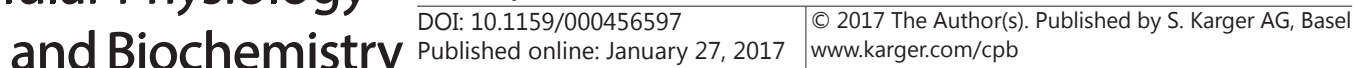

Chen et al.: miR-375 Roles in the Bovine Cumulus Cells

4 Albertini DF, Combelles CM, Benecchi E, Carabatsos MJ: Cellular basis for paracrine regulation of ovarian follicle development. Reproduction 2001;121:647-653.

-5 Ebner T, Moser M, Sommergruber M, Shebl 0, Tews G: Incomplete denudation of oocytes prior to ICSI enhances embryo quality and blastocyst development. Hum Reprod 2006;21:2972-2977.

6 Eppig JJ: Oocyte control of ovarian follicular development and function in mammals. Reproduction 2001;122:829-838.

7 McNatty KP, Moore LG, Hudson NL, Quirke LD, Lawrence SB, Reader K, HanrahanJP, Smith P, Groome NP, Laitinen M, Ritvos 0 , Juengel JL: The oocyte and its role in regulating ovulation rate: a new paradigm in reproductive biology. Reproduction 2004;128:379-386.

-8 Gilchrist RB, Thompson JG: Oocyte maturation: emerging concepts and technologies to improve developmental potential in vitro. Theriogenology 2007;67:6-15.

-9 Paulini F, Melo EO: The role of oocyte-secreted factors GDF9 and BMP15 in follicular development and oogenesis. Reprod Domest Anim 2011;46:354-361.

10 McIntosh CJ, Lun S, Lawrence S, Western AH, McNatty KP, Juengel JL: The proregion of mouse BMP15 regulates the cooperative interactions of BMP15 and GDF9. Biol Reprod 2008;79:889-96.

11 Edwards SJ, Reader KL, Lun S, Western A, Lawrence S, McNatty KP, Juengel JL:The cooperative effect of growth and differentiation factor- 9 and bone morphogenetic protein(BMP)-15 on granulosa cell function is modulated primarily through BMP receptorII. Endocrinology 2008;149:1026-1030.

12 Reader KL, Heath DA, Lun S, McIntosh CJ, Western AH, Littlejohn RP, McNatty KP, Juengel JL: Signalling pathways involved in the cooperative effects of ovine and murine GDF9+BMP15- stimulated thymidine uptake by rat granulosa cells. Reproduction 2011;14:123-131.

$\checkmark 13$ Mottershead DG, Ritter LJ, Gilchrist RB: Signalling pathways mediating specific synergistic interactions between GDF9 and BMP15. Mol Hum Reprod 2012;18:121-128.

-14 Peng J, Li Q, Wigglesworth K, Rangarajan A, Kattamuri C, Peterson RT, Eppig JJ, Thompson TB, Matzuk MM: Growth differentiation factor 9: bone morphogenetic protein 15 heterodimers are potent regulators of ovarian functions. Proc Natl Acad Sci USA 2013;110:E776-785.

15 Yan C, Wang P, DeMayo J, DeMayo FJ, Elvin JA, Carino C, Prasad SV, Skinner SS, Dunbar BS, Dube, Dube JL, Celeste AJ, Matzuk MM: Synergistic roles of bone morphogenetic protein 15 and growth differentiation factor 9 in ovarian function. Mol Endocrinol 2001;15:854-866.

16 McNatty KP, Juengel JL, Reader KL, Lun S, Myllymaa S, Lawrence SB, Western A, Meerasahib MF, Mottershead DG, Groome NP, Ritvos O, Laitinen MP: Bone morphogenetic protein 15 and growth differentiation factor 9 co-operate to regulate granulosa cell function. Reproduction 2005;129:473-480.

17 Peng J, Wigglesworth K, Rangarajan A, Eppig JJ, Thompson TB, Matzuk MM: Amino acid 72 of mouse and human GDF9 mature domain is responsible for altered homodimer bioactivities but has subtle effects on GDF9:BMP15 heterodimer activities. Biol Reprod 2014;91:142.

18 Mottershead DG, Sugimura S , Al-Musawi SL, Li JJ, Richani D , White MA, Martin GA, Trotta AP, Ritter LJ, Shi J, Mueller TD, Harrison CA,Gilchrist RB: Cumulin, an Oocyte-secreted Heterodimer of the Transforming Growth Factor- $\beta$ Family, Is a Potent Activator of Granulosa Cells and Improves Oocyte Quality. J Biol Chem 2015;290:24007-24020.

19 Moore RK, Otsuka F, Shimasaki S: Molecular basis of bone morphogenetic protein-15 signaling in granulosa cells. J Biol Chem 2003;278:304-310.

20 Pulkki MM, Myllymaa S, Pasternack A, Lun S, Ludlow H, Al-Qahtani A, Korchynskyi O, Groome N, Juengel JL, Kalkkinen N, Laitinen M, Ritvos O,Mottershead DG: The bioactivity of human bone morphogenetic protein-15 is sensitive to C-terminal modification: characterization of the purified untagged processed mature region. Mol Cell Endocrinol 2011;332:106-115.

21 Feng C, Liu H, Yang Y, Huang B, Zhou Y: Growth and differentiation factor-5 contributes to the structural and functional maintenance of theintervertebral disc. Cell Physiol Biochem 2015;35:1-16.

22 Williams LA, Wei A, Bhargav D, Diwan AD: Cartilage derived morphogenetic protein 2 - a potential therapy for intervertebral disc regeneration?. Biologicals 2014;42:65-73.

23 Ying X, Sun Y, He P: Bone Morphogenetic Protein-7 Inhibits EMT-Associated Genes in Breast Cancer. Cell Physiol Biochem 2015;37:1271-1278.

-24 Mazerbourg S, Klein C, Roh J, Kaivo-Oja N, Mottershead DG, Korchynskyi O, Ritvos O,Hsueh AJ: Growth differentiation factor- 9 signaling is mediated by the type I receptor, activin receptor-like kinase 5 . Mol Endocrinol 2004;18:653-665. 


\section{Cellular Physiology Cell Physiol Biochem 2017;41:439-450 \begin{tabular}{l|l} 
DOI: 10.1159/000456597 & $\begin{array}{l}\text { O 2017 The Author(s). Published by S. Karger AG, Basel } \\
\text { www.karger.com/cpb }\end{array}$ \\
\hline
\end{tabular}}

Chen et al.: miR-375 Roles in the Bovine Cumulus Cells

25 Vitt UA, Mazerbourg S, Klein C, Hsueh AJ: Bone morphogenetic protein receptor type II is a receptor for growth differentiation factor-9. Biol Reprod 2002;67:473-480.

26 Kaivo-Oja N, Mottershead DG, Mazerbourg S, Myllymaa S, Duprat S, Gilchrist RB, Groome NP, Hsueh AJ, Ritvos O: Adenoviral gene transfer allows Smad-responsive gene promoter analyses and delineation of type I receptor usage of transforming growth factor-beta family ligands in cultured human granulosa luteal cells. J Clin Endocrinol Metab 2005;90:271-278.

27 Jiang Z, Yu Q Xia L, Zhang Y, Wang X, Wu X, Gao Z: Growth Differentiation Factor-9 Promotes Fibroblast Proliferation and Migration in Keloids through the Smad2/3 Pathway. Cell Physiol Biochem 2016;40:207218.

-28 Reader KL, Mottershead DG, Martin GA, Gilchrist RB, Heath DA, McNatty KP,Juengel JL.KP, Juengel JL: Signalling pathways involved in the synergistic effects of human growth differentiation factor 9 and bonemorphogenetic protein 15. Reprod Fertil Dev 2016;28:491-498.

29 Liu S, Sun G, Yuan B, Zhang L, Gao Y, Jiang H, Dai L, Zhang J: miR-375 negatively regulates porcine preadipocyte differentiation by targeting BMPR2. FEBS Lett 2016;590:1417-1427.

-30 Su YQ, Sugiura K, Wigglesworth K, O'Brien MJ, Affourtit JP, Pangas SA, Matzuk MM, Eppig JJ: Oocyte regulation of metabolic cooperativity between mouse cumulus cells and oocytes: BMP15 and GDF9 control cholesterol biosynthesis in cumulus cells. Development 2008;135:111-121.

- 31 Caixeta ES, Sutton-McDowall ML, Gilchrist RB, Thompson JG, Price CA, Machado MF, Lima PF, Buratini J: Bonemorphogenetic protein 15 and fibroblast growth factor 10 enhance cumulus expansion, glucose uptake, and expression of genes in the ovulatory cascade during in vitro maturation of bovine cumulusoocyte complexes. Reproduction 2013;146:27-35.

32 Zhai B, Liu H, Li X, Dai L, Gao Y, LiC, Zhang L, Ding Y, Yu X, Zhang J: BMP15 prevents cumulus cell apoptosis through CCL2 and FBN1 in porcine ovaries. Cell Physiol Biochem 2013;32:264-278.

-33 Abir R, Fisch B, Johnson MH: BMP15, fertility and the ovary. Reprod Biomed Online 2014;29:525-526.

34 Pangas SA, Matzuk MM: The art and artifact of GDF9 activity: cumulus expansion and the cumulus expansion-enabling factor. Biol Reprod 2005;73:582-585.

-35 Shi FT, Cheung AP, Huang HF, Leung PC: Growth differentiation factor 9 (GDF9) suppresses follistatin and follistatin-like 3 production in human granulosa-lutein cells. PloS one 2011;6:e22866.

-36 Tuck AR, Mottershead DG, Fernandes HA, Norman RJ, Tilley WD, Robker RL, Hickey TE: Mouse GDF9 decreases KITL gene expression in human granulosa cells. Endocrine 2015;48:686-695.

-37 Yeo CX, Gilchrist RB, Thompson JG, LaneM: Exogenous growth differentiation factor 9 in oocyte maturation media enhances subsequent embryo development and fetal viability in mice. Hum Reprod 2008;23:67-73.

38 Gode F, Gulekli B, Dogan E, Korhan P, Dogan S, Bige O, Cimrin D, Atabey N: Influence of follicular fluid GDF9 and BMP15 on embryo quality. Fertil Steril 2011;95:2274-2278.

-39 Machado MF, Nogueira MF, Gilchrist RB, Sutton-McDowall ML, Mottershead DG, White MA, Thompson JG: Effect of cyclic adenosine monophosphate modulator regulators in association with bmp15 on bovine embryo development in vitro. Reprod Fert Develop 2014;27:207-208.

-40 Gilchrist RB, Lane M, Thompson JG: Oocyte-secreted factors: Regulators of cumulus cell function and oocyte quality. Hum Reprod Update 2008;14:159-177.

-41 McNatty KP, Smith P, Moore LG, Reader K, Lun S, Hanrahan JP, Groome NP, Laitinen M, Ritvos O, Juengel JL: Oocyte-expressed genes affecting ovulation rate. Mol Cell Endocrinol 2005;234:57- 66.

-42 McNatty KP, Galloway SM, Wilson T, Smith P, Hudson NL, O’Connell A, Bibby AH, Heath DA, Davis GH, Hanrahan JP, Juengel JL: Physiological effects of major genes affecting ovulation rate in sheep. Genet Sel Evol 2005;37:S25-38.

43 McNatty KP, Juengel JL, Reader KL, Lun S, Myllymaa S, Lawrence SB, Western A, Meerassahib MF, Mottershead DG, Groome NP, Ritvos O, Laitinen MP: Bone morphogenetic protein 15 and growth differentiation factor 9 co-operate to regulate granulosa cell function in ruminants. Reproduction 2005;129:481-487. 